Laura A. Janda* and Antonio Fábregas

\title{
Seeing from without, seeing from within: Aspectual differences between Spanish and Russian
}

https://doi.org/10.1515/cog-2018-0054

Received 09 May 2018; revised 30 November 2018; accepted 05 December 2018

Abstract: Linguistic categories such as aspect are not identical across languages, and cross-linguistic differences can reveal differences in construal and conceptual categorization, which are key concepts in cognitive linguistics. SpanishRussian parallel data diverge in situations where Spanish uses a Perfective Past tense form, while the Russian translation equivalent is an Imperfective Past tense form. We classify examples of aspectual mismatch according to grammatical constructions and language-specific facts. We find this mismatch in contexts with overt expression of time periods, as well as situations in which a final temporal boundary either is expressed or can be inferred. We interpret this in terms of a difference in conceptualization: Spanish has a tendency to view time periods from without, interpreting them as bounded and thus Perfective, whereas Russian has a tendency to view time periods from within, interpreting them on the basis of their duration without reference to their boundaries and thus Imperfective.

Keywords: aspect, perfective, imperfective, Spanish, Russian, corpus, translation

\section{Introduction}

It was a dark and stormy night. In order to prove his love for Bea, Daniel had to meet her in the abandoned mansion at the appointed hour. Trembling in his rain-drenched clothes, Daniel pushes open the heavy oak door. In the Spanish original La Sombra del Viento (Ruiz Zafón 2001: 278), Bea reacts by saying:

\footnotetext{
*Corresponding author: Laura A. Janda, Department of Language and Culture, UiT The Arctic University of Norway, Tromsø, Norway, E-mail: laura.janda@uit.no

Antonio Fábregas, Department of Language and Culture, UiT The Arctic University of Norway, Tromsø, Norway, E-mail: antonio.fabregas@uit.no 
(1a)

$\begin{array}{llll}\text { Cre-i } & q u e & \text { no } & \text { ven-dría-s } \\ \text { [think-PST.PFV.1SG } & \text { that } & \text { not } & \text { come-COND-2sG] }\end{array}$

'I thought you weren't coming' [English translation Ruiz Zafón 2004: 229]

The Russian equivalent (Russian translation Ruiz Zafón 2016: 278) ${ }^{1}$ reads as follows:

(1b)

Ja duma-l-a, ty ne prid-e-šs

[I.NOM think.IPFV-PST-F.SG you.NOM not arrive.PFV-NPST-2SG

In Spanish the first verb is a Perfective Past tense form, but in Russian it is an Imperfective Past tense form. Bea conveys the same message, but she does it differently depending upon which language she is speaking. In Spanish, aspect is part of the verb's Past tense inflection, and Perfective is the default choice because Daniel has already arrived, so thinking that Daniel won't come has been delimited by a boundary: the moment in which Daniel arrived. In Russian, aspect is a characteristic of the verb stem, and Imperfective is the most normal option because thinking that Daniel would fail to come extended over a time period with some duration. Our conclusion, argued in detail below, is that in Spanish Bea sees her thinking from the outside as a bounded event, whereas in Russian Bea sees her thinking unfolding over time from the inside.

If we look at example (1) in terms of Vendlerian classes, thinking is an Activity and arriving is an Achievement. The critical difference is in whether the thinking Activity is conceptualized as bounded, as in Spanish, or as unbounded, as in Russian. From the perspective of Cognitive Grammar (Langacker 1987, Langacker 2008), Spanish in this example conceptualizes this Activity externally via "summary scanning", whereas the Russian equivalent conceptualizes the same Activity internally via "sequential scanning”.

Ours is a study of the "same” grammatical category, which isn't really the same across languages. Both Spanish and Russian have a Perfective vs. Imperfective distinction, and this distinction seems to be similar in the two

1 Henceforth we use abbreviations in square brackets to cite the sources of examples. S (for Spanish) = Ruiz Zafón 2001, R (for Russian) = Ruiz Zafón 2016, and E (for English) = Ruiz Zafón 2004. Letter abbreviations are followed by a page number, and for Spanish and Russian equivalents also by an ID number for each verb. Citations from the Russian National Corpus (RNC, ruscorpora.ru) appear with abbreviated metadata "passports". All examples are from either the Zafón novel or the RNC, except: (3) and (4), which come from Internet sites; (5), which is a book title; and (15), which comes from a Spanish corpus. 
languages, yet there are examples like (1), where the languages show opposite tendencies. Such examples are evidence that the grammatical category of aspect is not really the same across languages, and indeed that all grammatical categories are to some extent language-specific as claimed by Croft (2001: Ch. 1; with respect to aspect, 2012: 127). ${ }^{2}$ We offer an in-depth study of what this means for aspect in Spanish and Russian, revealing an important and pervasive difference in the "thinking for speaking" (Slobin 1996) concerning the conceptualization of time in the two languages. Our study is among the first corpus-based studies to focus specifically on aspectual mismatches between Spanish and Russian indicative Past tense verb forms. ${ }^{3}$

Comrie (1976: 7) states that "in discussing perfective and imperfective meaning, the easiest examples to work with are from, for instance, Russian and Spanish", yet there has been little work on this cross-linguistic comparison. Díez (2002) cites correspondences in which both languages use the same aspect in the Past tense, without discussing any systematic differences. Gorbova (2002) finds that native Spanish speakers vary in their assessment of the acceptability of Perfective vs. Imperfective (cf. similar results in García and Van Putte 1988; de Jonge 2000), but leaves open the question of whether aspect can be intentionally manipulated in Spanish the way aspect can be manipulated in Russian to highlight varying construals of a given situation. Kargovskaya (2012) lists typical errors made by Russians learning Spanish, among them overuse of Spanish Imperfective forms in sentences with an overt expression of duration or of specific number of repetitions, where Spanish prefers Perfective, while Russian prefers Imperfective. We put these observations in the perspective of a corpus study, thus detailing the scope of this phenomenon.

We survey theoretical issues and give an overview of aspect in Spanish and Russian in Section 2. Section 3 presents our data and identifies the strongest point of disconnection between Spanish and Russian aspect, namely the use of Perfective in Spanish that corresponds to Imperfective in Russian (Spanish $\mathrm{PFV}=$ Russian IPFV mismatch). In Section 4 we inventory the constructions associated with the Spanish PFV = Russian IPFV mismatch and show that a single

2 Of course, the palette of aspectual distinctions available in languages is much broader than the Perfective vs. Imperfective distinction that is the focus of this article; cf. Plungian (2011: Ch. 7).

3 Note that our study focuses specifically on the Perfective and Imperfective Past tense forms in Spanish and Russian. The Spanish Perfect (as in he cantado "I have sung") is beyond the scope of this article, but is the topic of work by Gorbova $(2013,2014)$ who argues that the Perfect is encroaching on the semantic territory of the Perfective Past tense in Spanish, using parallel corpus data from Russian to support this analysis. 
conceptual difference explains the difference between aspect in the two languages across these constructions. We summarize our findings in Section 5.

\section{Theoretical considerations and aspect in Spanish and Russian}

The main claim of this article is that Spanish and Russian conceptualize in different ways the notion of perfectivity, which is implemented in each language in a different way. This section reflects these two levels of abstraction: the first subsection presents the main intuitions about Perfective vs. Imperfective in abstract terms that apply to the two languages considered here. Section 2.2 discusses the contrast specifically for Spanish, and Section 2.3 does the same for the case of Russian.

\section{1 (Im)perfectivity in abstract terms}

A common intuition that underlies semantic approaches to (im)perfectivity is that Perfective conceives a situation as a bounded whole limited by a starting time point and a termination point (see Figure 1(a)), while Imperfective aspect presents the situation without its boundaries, focusing on its internal constituency independently from its beginning or end (see Figure 1(b)) (Jakobson 1971a; Comrie 1976; Dahl 1981; Klein 1994; De Swart 2011; Gvozdanović 2011).

a.

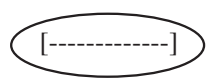

b.

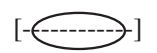

Figure 1: Perfective (a) and Imperfective (b) aspect.

In Figure 1, the situation with its temporal extension along the horizontal axis is marked with dashes, and the initial and final boundaries of the situation are marked with square brackets. The ellipse captions the way the two aspects present the situation, with Perfective (Figure 1(a)) including the entire situation from an external perspective with the ellipse including the boundaries, as opposed to Imperfective (Figure 1(b)) which takes an internal perspective where the ellipse does not extend to the boundaries. 
This intuition has been captured in different ways. Jakobson (1971a) claimed that the Perfective category (in Slavic) denotes that the final boundary of the event has been attained, while Klein's (1994) analysis assumes that Perfective and Imperfective are types of viewpoint aspect which differ with respect to the relation established between the running time of the situation (Time of the situation, TSit) and the period of time which the speaker confines the statement to (Topic Time, TT). From this perspective, Perfective aspect selects a TT inside of which the situation is totally included, from beginning to end, while Imperfective aspect introduces a TT which is properly included within TSit, so that the initial and final endpoints are excluded. In (2), the sign “ + " represents the running time of the situation, and parentheses delimit the period corresponding to TT.

(2a) Perfective: TSit properly included within TT

-----(-++++++++++++++++-)----

(2b) Imperfective: TT properly included within TSit

$----+(++++++++++++++)+-\cdot-\cdot-$

Abstracting away from the specific technical implementations adopted, the relation between the situation's boundaries and the time period that the claim is restricted to has been considered responsible for the contrast between Perfective and Imperfective. By virtue of conceptualizing the situation as bounded, Perfective aspect has been related to holistic, delimited construals, while Imperfective aspect captures notions where the boundaries are irrelevant or even could not exist, such as progressive forms of a single situation, unbounded habitual occurrences of a situation or generic descriptions not confined to any specific time period (cf. Krifka et al. 1995; Carlson 2011; Arche 2014, among many others). In an abstract sense, Perfective conceives the situation as a count object, because it defines it within delimited boundaries, while Imperfective presents the same situation as a mass object, without defined boundaries (cf. Langacker 1987: 248-267).

However, this abstract notion of (im)perfectivity is perhaps too general for languages to operate with, and it is expected that different languages will categorize it in distinct ways (cf. Dahl 1981; Plungian 1998; Croft 2012). There are several senses in which these general notions can be made more concrete: for instance, is the duration of the situation contained within the boundaries relevant for the definition of (im)perfectivity? Is it enough if the situation is only bounded on one side? What if one singles out one single point in time within the running time of the event? Do the boundaries of each individual occurrence 
within a series of events count for perfectivity or not? Our view is that Russian and Spanish have taken different decisions about how (im)perfectivity is conceptualized in the form of specific distinct choices inside the abstract space defined by these two categories.

\section{2 (Im)perfectivity in Spanish: Background}

In Spanish the contrast is between two Past tenses, the Perfective preterito indefinido (cant-o [sing-PST.PFV.3SG] "s/he sang") and the Imperfective pretérito imperfecto (cant-aba [sing-PST.IPFV.3SG] "s/he sang”).

There is no agreement with respect to how this contrast should be characterized, although the dominant view assigns Perfective aspect to the indefinido and Imperfective to the imperfecto (Gili Gaya 1943: § 120; Alarcos Llorach 1949; Bull 1960; García Fernández 2000; RAE \& ASALE 2009: § 23.10; Gras and Santiago 2012; Fábregas 2015; Palacio Alegre 2016). Interestingly, this is also the dominant view from a Cognitive perspective and in language teaching works: Ruiz Campillo (2000, 2005); Castañeda and Alonso (2009); Palacio Alegre (2009); Castañeda and Alhmoud (2014) have all argued that the real distinction refers to the perspective adopted by the speaker when presenting the action: Imperfective would correspond to a perspective from inside the action, excluding its ending. This view contrasts with the alternative theory, whose antecedent is Bello (1847), that treats the opposition as one that reflects a difference in the referential properties of Past tense. Rojo $(1974,1976)$ argues that Perfective refers to a past period deictically - taking as the reference point the time of utterance - while Imperfective has anaphoric reference to a past period contextually determined through linguistic or extralinguistic means (cf. Hernández Alonso 1984; Rojo and Veiga 1999; Veiga 2015). In this article we assume the first, more dominant explanation and therefore consider this contrast aspectually-based. In the following paragraphs we will describe the main aspectual uses of the Imperfective in Spanish (see, in addition to the texts cited above, Alcina and Blecua 1975; Arche 2014; Bertinetto 2004; Brucart 2003; Carrasco and García Fernández 1994; De Mello 1989; Doiz Bienzobas 1995; García Fernández 2004; Gutiérrez Araus 1995; Zagona 2012).

There are three contexts where Imperfective is used almost exclusively. The first is in habitual statements. Here, the choice of Imperfective involves talking about an unbounded series of frequent and regular episodes of the same situation (3). Perfective cenó "dined" would be used to pick out any of the specific episodes of dining. 
(3) Tesla [...] cen-aba [dine-PST.IPFV.3SG] cada día a la misma hora en el mismo restaurante.

'Tesla dined every day at the same time in the same restaurant'

[actualidad.rt.com July 11, 2017]

The second context where Spanish must use Imperfective is to express ongoing actions. In (4), Imperfective triggers a reading where the situation period highlighted is previous to the (possible) completion of the event; that is, the person is caught by the police while traveling at full speed. With Perfective, the reading would be that the person gets caught after finishing the trip.

(4) La policía lo detuvo cuando viaj-aba [travel-PST.IPFV.3SG] a toda velocidad. 'The police detained him when he was traveling at full speed'

[univision.com February 1, 2018]

Finally, Imperfective is also used with stative predicates, unless there is an overt expression that measures the duration of the state or expresses a termination boundary (such as durante dos dias "for two days" or hasta las tres "until three o'clock"). The sentence in (5), which is the title of a book by M. Carme Bernal, uses Imperfective because there is no dynamic event but rather a homogeneous state.

(5) La princesa que est-aba [be-PST.IPFV.3SG] enferma 'the princess that was sick'

This use is generally with stative predicates like tener una casa "have a house" or saber inglés "know English". Consequently, several stative verbs are recategorized as expressing a change of state when used in Perfective, as for instance pudo "managed" (vs. Imperfective podía "was able to"), supo "got to know, discovered" (vs. Imperfective sabía "knew") or tuvo "got” (vs. Imperfective tenía "had"). The intuitive idea that the Imperfective form is used when there are no boundaries, or when the situation boundaries are excluded from the claim made in the sentence fits with the abstract definition of Imperfective aspect given above. ${ }^{4}$

4 We leave aside so-called modal uses of Imperfective in Spanish (cf. RAE and ASALE 2009: $\S 23.11 \mathrm{~d}$ and following). 


\section{3 (Im)perfectivity in Russian: Background}

Perfective vs. Imperfective in Russian has much in common with the like-named distinction in Spanish. In both languages, Perfective is associated with bounded and sequenced events, whereas Imperfective is associated with events that are habitual or simultaneous with other events. But as indicated above in Section 1, this distinction is not identical across the two languages. ${ }^{5}$

A major difference between Russian and Spanish is revealed in the glossing of example (1), where aspect appears as part of the verb stem in Russian, rather than as part of its inflection (as in Spanish). ${ }^{6}$ In Russian, an entire verb is Perfective or Imperfective and aspect is expressed in all verb forms, rather than being restricted to the Past tense (as in Spanish). For the majority of Russian verbs, aspectual derivational morphology (presence vs. absence of prefixes and/or suffixes) on the stem overtly marks Perfective vs. Imperfective. Finiteness, mood, and tense are expressed by means of inflectional suffixes, and these receive their interpretation in combination with the aspect of the stem. For example, Non-past tense forms are usually interpreted as Future tense with Perfective stems, but as Present tense with Imperfective stems. While the focus in this article is on expression of the aspect of past events, a brief discussion of the meaning of aspect in Russian in general is in order.

A copious scholarly literature on Russian aspect details the ways in which Perfective vs. Imperfective verbs are used to portray events (see citations in Dickey 2000; Zaliznjak and Šmelev 2000; Timberlake 2004; Janda 2007b; Janda et al. 2013; Dickey and Janda 2015). From a structuralist perspective, analyses in terms of features (such as "boundedness" and "totality" cf. Jakobson 1971b; Maslov 1965; Forsyth 1970; Vinogradov 1972) describe Perfective as expressing an event with respect to its boundaries or completion, as opposed to Imperfective as lacking any reference to boundaries or completion, and likewise Croft (2012: 125) refers to the Russian distinction as one of "boundedness/unboundedness". This binary distinction is similar (but not identical) to Langacker's (2008: Ch. 3) summary scanning in which Perfective profiles the completion of an event, as opposed to sequential scanning in which Imperfective does not profile completion.

\footnotetext{
5 Spanish additionally distinguishes Progressive, which is entirely lacking in Russian. For a detailed comparison of the Spanish Progressive and how it corresponds to Russian verb forms, see corpus examples and experiments reported in Gorbova (2010). The Spanish Progressive is not within the scope of this article.

6 Note that some scholars have treated Russian aspect as inflectional. See discussion in Janda (2007a).
} 
Janda (2004) describes Russian aspect in terms of an isomorphism between the properties of matter and those of events, using the metaphors PERFECTIVE IS A DISCRETE SOLID OBJECT vs. IMPERFECTIVE IS A FLUID SUBSTANCE. According to this model, discrete solid objects motivate the recognition of bounded whole events that do not occupy the same temporal location (i.e., tend to be sequenced) as one type, namely Perfective. By contrast, fluid substances motivate the recognition of events that are extensive and can be spread or intermingled (i.e., can be simultaneous) as a different type, namely Imperfective. Janda (2012), and Dickey and Janda (2015) demonstrate parallels between the behavior of numeral classifiers, which specify bounded count nouns, typically according to their shapes, and Russian perfectivizing prefixes, which specify bounded events, typically according to their temporal contours.

For the present study, the behavior of Russian aspect with respect to temporal measures and boundaries is particularly relevant. Janda's (2004) model shows how Perfective is used when an event has inherent boundaries, parallel to the way that a ruler can measure the dimensions of a solid object. However, when an event lacks inherent boundaries, Imperfective is used even when limits are given that contain the event. This is motivated by the conceptualization of Imperfective as a fluid substance which can fill a container, like water in a cup. The water does not have edges of its own; the cup is not part of the water even though the water takes on the shape of the cup. Example (6) demonstrates this difference with two events, both of which are cited with temporal limits.

(6) on možet tri čas- $\boldsymbol{a}$ [three.ACc hour-GEN.SG] tanceva-t' [dance.IPFV-INF] bez ustali, pro-čita-t' [through-read.PFV-INF] za den' [in day.Acc.sG] celikom anglijskij detektivnyj roman

'he can dance for three hours without getting tired, read a whole English detective novel in a day'

[Jurij Trifonov 1970, RNC]

Reading a novel from beginning to end is an accomplishment with inherent boundaries since it begins on page one and ends on the last page. This is like a solid object; the distance between its edges can be measured. This event is signaled by a Perfective verb measured by a day, which has a beginning and end that are linked to the beginning and end of the reading event. Dancing, however, does not have inherent boundaries. It can be measured only by using a time period as a container. The three hours have a beginning and an end, but those are not linked to inherent structures in the dancing event, which is expressed by an Imperfective verb and measured out like three cups of water. 
Example (6) shows that even in situations where temporal boundaries exist, Russian can (and usually must) use the Imperfective if the boundaries are not perceived as part of or relevant to an event. As detailed by Janda (2004), there are several uses of the Russian Imperfective that direct the focus away from boundaries: for example, in Russian the Imperfective is preferred when a manner adverb is used (directing focus internal to the event), when an event is backgrounded (so-called "general-factual"), and when an action is annulled. As shown in Section 4, these uses pattern with the Perfective in Spanish, signaling that Spanish conceptualizes Perfective merely by whether it carries boundaries or not: when the fluid that otherwise could be expressed as Imperfective is placed inside a container with boundaries, those boundaries are enough to trigger a reclassification of the form as Perfective.

\section{Data sources and dimensions of Spanish-Russian aspectual mismatch}

Two databases were constructed to give an overall perspective on the dimensions of aspect in Spanish and Russian, one based on Ruiz Zafón's (2001) novel and its Russian translation cited in Section 1, and one based on data in the Spanish-Russian parallel corpus that is part of the Russian National Corpus (ruscorpora.ru). About 100 pages (16\%) of the novel were hand-coded in a spreadsheet with 5009 lines, each line containing a verb form in one or both languages and the equivalent form in the opposite language, along with the full sentences in which the forms appeared, and a parse of the relevant forms. In this sample (called "Sombra"), the quantity of Perfective and Imperfective forms in Spanish was perfectly balanced, with 967 forms of each. In addition, the Spanish-Russian portion of the Russian National Corpus ("RNC") was queried for Spanish Past Perfective forms, yielding 373 sentences with Russian equivalents, and for Spanish Past Imperfective forms, yielding 528 sentences (these totals reflect search results after removal of spurious data, such as hacia "toward", which the corpus did not distinguish from hacia, an Imperfective Past form of hacer "do, make"). All verbs in both languages in this sample were likewise aligned and parsed by hand.

Since the Russian data is translation equivalents, it is reasonable to ask how well this data represents the behavior of verbs in Russian as a whole. In Table 1 we compare the distribution of Russian verb forms in the Sombra translation with that in the Russian National Corpus (cf. Janda and Lyashevskaya 2011: 723). 
Table 1: Comparison of distribution of Russian verb forms in RNC and in Russian translation of La Sombra del Viento.

\begin{tabular}{lrrrrr}
\hline & \multicolumn{2}{c}{ Russian Imperfective forms } & & \multicolumn{2}{c}{ Russian Perfective forms } \\
\cline { 2 - 3 } \cline { 5 - 6 } & In RNC & In Sombra translation & & In RNC & In Sombra translation \\
\hline Non-Past & $42.42 \%$ & $22.41 \%$ & $9.83 \%$ & $8.36 \%$ \\
Past & $29.51 \%$ & $49.15 \%$ & $51.16 \%$ & $57.25 \%$ \\
Infinitive & $14.60 \%$ & $9.75 \%$ & $17.50 \%$ & $16.72 \%$ \\
Imperative & $2.25 \%$ & $2.21 \%$ & $2.96 \%$ & $2.06 \%$ \\
Gerund & $4.85 \%$ & $9.05 \%$ & $3.03 \%$ & $4.13 \%$ \\
Participle & $6.37 \%$ & $7.44 \%$ & $15.52 \%$ & $11.48 \%$ \\
\hline
\end{tabular}

This comparison uses the main corpus of the RNC (and does not include data in the Spanish-Russian parallel corpus portion of the RNC).

In the rightmost columns of the top row of Table 1 we see, for example, that $8.36 \%$ of Perfective verb forms in the Russian translation are Non-Past forms, as compared to $9.83 \%$ in the RNC. In general, the picture is very similar everywhere except for the Non-Past and Past forms for Imperfective verbs, where the relative frequencies are flipped. This may be due to the fact that the novel is written in the Past tense, encouraging somewhat higher use of Past tense than usual. We do not undertake a statistical test because the two sets of data are on very different scales (the Sombra sample is just under 25,000 words, while the RNC main corpus has hundreds of millions of words). This comparison indicates that we are not dealing with a seriously deviant sample of Russian.

Perhaps a larger question is: To what extent do the Spanish language samples from Ruiz Zafón's novel and the Spanish parallel corpus of the RNC represent the Spanish language as a whole? Due to the complexity and geographical dispersion of the Spanish-speaking community, there is no easy answer to this question. We can therefore be certain that our results are valid only for these samples.

Table 2 gives an overview of the distribution of Spanish Past tense forms and their translation equivalents in the two databases.

The top half of Table 2 shows data for Spanish Perfective verb forms (PST. PFV) and their Russian equivalents, while the bottom half shows data for Spanish Imperfective verb forms (PST.IPFV) and their equivalents. All data is stated both in terms of percentages and raw numbers (in parentheses). The table is coded to highlight both aspectual matches (shaded in light gray) and aspectual mismatches (shaded in a darker tone of grey). For example, if we look at the Sombra sample for Spanish Perfectives, we see that there were 967 total 
Table 2: Distribution of Russian equivalents to Spanish Past tense forms in two samples.

\begin{tabular}{llrr}
\hline & & $\begin{array}{r}\text { La Sombra del Viento } \\
\text { sample (Sombra) }\end{array}$ & $\begin{array}{r}\text { Russian National Corpus Spanish } \\
\text { parallel corpus sample (RNC) }\end{array}$ \\
\hline $\begin{array}{c}\text { Spanish } \\
\text { PST.PFV }\end{array}$ & Total Spanish PST. & $100 \%(967)$ & $100 \%(373)$ \\
& $>$ Russian PFV-PST & $74.4 \%(719)$ & $55.5 \%(207)$ \\
& $>$ other Russian PFV & $2.1 \%(20)$ & $7.5 \%(28)$ \\
& $>$ Russian IPFV-PST & $11.1 \%(107)$ & $18.5 \%(69)$ \\
& $>$ other Russian IPFV & $1.6 \%(15)$ & $3.5 \%(13)$ \\
& $>$ no verb in Russian & $11 \%(106)$ & $16.1 \%(60)$ \\
Spanish & Total Spanish PST. & $100 \%(967)$ & $100 \%(528)$ \\
PST.IPFV & IPFV & $59.4 \%(574)$ & $53.8 \%(284)$ \\
& $>$ Russian IPFV-PST & $12.4 \%(120)$ & $11.4 \%(60)$ \\
& $>$ other Russian IPFV & $5.8 \%(56)$ & $5.1 \%(27)$ \\
& $>$ Russian PFV-PST & $2.4 \%(23)$ & $2.7 \%(14)$ \\
& $>$ other Russian PFV & $20.1 \%(194)$ & $27.1 \%(143)$ \\
\hline
\end{tabular}

examples. 719 of these ( $74.4 \%$ of the total) were matched by Russian Perfective Past tense forms (PFV-PST), and an additional 20 examples (2.1\%) also used a Russian Perfective verb (other Russian PFV), though not a finite Past tense form. Collectively we see that a Spanish Perfective form is mostly rendered as a Perfective in Russian $(74.4 \%+2.1 \%=76.5 \%$ in Sombra and $55.5 \%+7.5 \%=63 \%$ in the RNC). However, the remaining data on the Spanish Perfective forms is rather evenly distributed between examples where a Russian Imperfective verb is used or there is no overt verb equivalent in Russian (Russian expresses this meaning with an adjective, adverb, noun, prepositional phrase, zero copula, or the predicative net "no"). In parallel fashion, the bottom half of Table 2 begins with the total number of Spanish Imperfective forms for each database, and then details how many of those are matched by Russian Imperfective Past tense forms, expressed by other Russian Imperfective forms, mismatched by Russian Perfective Past tense forms, expressed by other Russian Perfective forms, or not expressed by an overt verb form in Russian.

The strongest deviation between the two languages is in the aspectual mismatch involving Spanish Perfective vs. Russian Imperfective, with $11.1 \%+$ $1.6 \%=12.7 \%$ mismatch for Sombra and 18.5\% $+3.5 \%=22 \%$ mismatch for the RNC. The remainder of this article focuses on this type of mismatch and the constructions that motivate it, discussed in detail in Section 4. 


\section{When does Spanish perfective = Russian imperfective?}

Our analysis is in terms of construction types that motivate Spanish speakers to select Perfective forms, but motivate Russian speakers to select Imperfective forms. Three construction types involve temporal bounding that is either overtly expressed (4.1 and 4.2) or logically deduced (4.3). Spanish tends to view these time periods as eventualities ${ }^{7}$ closed by boundaries, and therefore Perfective. While the default Russian option is to view the same events from inside, as durational and therefore Imperfective, Russian does have the option, at least in some instances, to use special marking (prefixes and prepositions) to move the observer outside and express such events as Perfective. A fourth type (4.4) involves both aspectual and temporal mismatch, where Russian invokes a historical present in place of Spanish Past tense narration. All remaining types are collected and explained as lexical or idiomatic phenomena (4.5).

\subsection{Time periods filled with an event}

The most striking constructional type in our data involves the specification of time periods that are filled with some event. This is achieved either by a construction with a prepositional phrase (like Spanish durante décadas, Russian $v$ tečenie desjatiletij "over the course of decades"), a numeral phrase (like Spanish cinco minutos, Russian pjat' minut "five minutes"), or a noun phrase denoting a time span (like Spanish toda la noche, Russian vsju noč' "all night)". In this constructional type, the Spanish and Russian default options point in the opposite aspectual directions for the same reason. Spanish requires (or prefers) Perfective because a bounded time period is named, meaning that the event in question is delimited by measuring the duration and therefore can be seen from without as a closed package. Russian, however, requires (or prefers) Imperfective because a time period is named, meaning that the event can be viewed from within as a duration. All three means of marking time periods are illustrated in examples (7)-(9):

7 Here we adopt the term eventuality (from Bach 1986) as covering both states and (dynamic) events; as will be clear in the examples below, Spanish uses Perfective also with states provided they are bounded. Notice that our conclusions are consistent with Westerholm's (2010: 108-116) observation that delimitedness and duration are separate, although related, notions. 
(7) Preposition + time expression

Esta es la historia de cómo uno de los hombres más poderosos de la Francia medieval asesin-ó [murder-PST.PFV.3SG] impunemente durante década-s [during decade-PL] por pura diversión

Èto istorija o tom, kak odin iz samyx moguščestvennyx ljudej srednevekovoj Francii $v$ tečeni-e desjatiletij [in course-ACC.SG decade.GEN.PL] beznakazanno ubiva-l [murder.IPFV-PST.M.SG] isključitel'no radi razvlečenija

'This is the story of how one of the most powerful men in medieval France over the course of decades murdered with impunity just for amusement' [César Cervera 2017.01.18, RNC]

(8) Numeral + time noun

No sabe usted el miedo que pasé el día que le pedí permiso para casarme con su hija y se tir-ó [cast-PST.PFV.3SG] cinco minuto-s [five minute-PL] mirándome fijamente [S97:27]

Vy i predstavit' ne možete, kakogo straxu ja naterpelsja $v$ tot den', kogda poprosil u nego ruki ego dočeri: on smotre-l [look.IPFV-PST.M.SG] na menja pristal'no cel-yx pjat' minut [whole-GEN.PL five.ACC minute.GEN. PL] [R81:61]

"You can't imagine how scared I was the day I asked him for his daughter's hand and he spent five long minutes staring at me” (E74)

(9) Other time period-denoting nominal expression

Ley-ó [read-PST.PFV.3SG] toda la noche [all the night], ajeno a los ronquidos de las religiosas y a las estaciones fugaces en la niebla. [S42:21]

On čita-l [read.IPFV-PST.M.SG] vs-ju noč’ [all-ACC.F.SG night.ACC.sG] naprolet, ne zamečaja ni xrapa svoix sputnic, ni mel'kanija okutannyx dymkoj stancij. [R26:35]

'He read all night, unaware of the nuns' snoring or of the stations that flashed by in the fog.' [E24]

In these three examples, the killing, the looking, and the reading all fill the respective named time periods of decades, five minutes, and the whole night. And in all three examples, the Spanish verbs appear in the Perfective Past tense forms, while the corresponding Russian verbs are Imperfective. While these expressions define boundaries in both languages, only Spanish treats them as relevant in order to determine aspect because they define a delimited quantity of 
the eventuality. Russian, instead, focuses on the duration and chooses Imperfective accordingly.

Another way of delimiting an action is by stating the number of times it occurred with a cardinal numeral. As example (10) shows, the same pattern obtains: Spanish views a number of repetitions from without focusing on the boundary defined by them and accordingly using Perfective verb forms, whereas Russian typically emphasizes the repetition by viewing the same series from within using Imperfective verbs.

(10) Iteration through cardinal numerals

Tres vece-s [three time-PL] intent-é [try-PST.PFV.1SG] seguir una ruta que había creído memorizar, y tres vece-s [three time-PL] me devolvió [return-PST.PFV.3SG] el laberinto al mismo punto del que había partido. [S98:25]

Triždy [three.times] pyta-l-sja [try.IPFV-PST.M.SG-REFL] ja projti putem, kotoryj, kak mne kazalos’, pomnil, i triždy [three.times] labirint vozvrašča-l [return.IPFV-PST.M.SG] menja na točku starta. [R82:62]

'Three times I tried to follow a path I thought I had memorized, and three times the maze returned me to the same point.' [E75]

A search in the RNC parallel corpus was carried out using Spanish durante "during" as the query. After these results were cleaned to represent only uses involving time periods and indicative Past tense verb forms in Spanish, 60 examples remain. Of those, 7 have a Russian translation that does not closely parallel the Spanish, leaving 53 relevant parallel examples. 42 of these examples (79\%) show the Spanish PFV=Russian IPFV mismatch: 40 with Imperfective indicative Past forms in Russian, and 2 with Russian Imperfective Past active participles. These examples show that the Spanish PFV = Russian IPFV mismatch can obtain no matter how long or short the time period is, ranging in this sample from an entire century to a single second or even an instant, as in these examples:

(11) La calle Mariana desemboca en la peatonal calle de las Tiendas (17), hoy muy comercial, se abrió en el siglo XI, y durante el siglo XVI [during the. M.SG century XVI] fu-e [be-PST.PFV.3SG] la antigua calle de las Lencerías. Ulica Marianna (calle Mariana) vyxodit na pešexodnuju ulicu T'endas (calle de las Tiendas) (17), kotoraja segodnja otličaetsja bojkoj torgovlej, a pojavilas' ešče v XI veke i $\boldsymbol{v}$ XVI vek-e [in XVI century-LOc.sG] by-l-a [be. IPFV-PST-F.SG] drevnejšej ulicej Lenserias (calle de las Lincerias). 
'Mariana street leads to the pedestrian route Tiendas (Market) street (17), which is today very commercial, appeared in the $11^{\text {th }}$ century, and during the $16^{\text {th }}$ century was the ancient Lencerias (Lingerie) street.'

[Junta de Andalucía. Almería 2015, RNC]

(12) La mir-ó [look-PST.PFV.3sg] durante un segundo [during one.M.sG second], sin comprender.

Sekund-u [second-Acc.sG] on smotre-l [look.IPFV-PST.M.SG] na nego, ne ponimaja.

'He looked at it [the pistol] for a second, without comprehending.'

[A.N. Strugackij, B.N. Strugackij 1972, RNC]

(13) Dud-é [doubt-PST.PFV.1SG] un instante [one.M.SG instant]. [S101:7]

Kak-oe-to mgnoveni-e [some-ACC.N.SG-certain instant-ACC.SG] ja kolebal-sja [waver.IPFV-PST.M.SG-REFL]. [R85:58]

'I hesitated for a moment.' [E77]

The situations described by the verbs in these three examples fill the entire time period of the sixteenth century in the first example, a single second in the second example, and an instant in the third. Yet despite the difference in duration, Spanish always views the event from without, using a Perfective Past tense form, while the corresponding event is viewed from within and expressed with a Past tense form of an Imperfective verb in Russian.

The remaining 11 examples from the RNC give evidence of ways in which the two languages can override the usual default aspect in the presence of a time period: 3 examples have an Imperfective verb form in both languages, and 8 examples have a Perfective verb in both languages.

The main way in which Spanish can change its default point of view is by defining an eventuality as habitual and therefore non-episodic, that is, not linked to any specific instantiation of the eventuality on a specific occasion (14). Here the author is describing a repeated daily routine in which the prisoners try to get warmed up again. Interestingly, in the case of habits the nature of the time expression introduced with durante is less specific, and therefore less likely to define concrete boundaries. Notice that here the nominal expression is interpreted as referring to the last sweet minutes of each typical day within the timespan that the routine occupies. This contrasts with the examples above, where the time expression was either referring to a unique specific period (the sixteenth century) or a portion of time contained in a specific single time unit (five minutes on a specific day, for instance). 
...todos se habían camuflado y se recalent-aba-n [heat-PST.IPFV-3PL] durante lo-s últim-o-s dulce-s minuto-s [during the.M-PL last-M-PL sweet-PL minute-PL].

...vse pritknulis' $i$ grej-ut-sja [heat.IPFV-NPST.3PL-REFL] posledn-ie sladkie minut-y [last-ACC.PL sweet-ACC.PL minute-ACc.PL].

'they all got under cover and were/are getting warmed up during those last sweet minutes.'

[A.I. Solženicyn 1961, RNC]

There are however cases in Spanish where the habituality overrides the boundaries set by durante even if the nominal expression is specific and not repeated, as in the following example:

(15) ... el hijo de una campesina que me visita-ba [visit-PST.IPFV.3SG]durante mi enfermedad

'... the son of a peasant that used to visit me during my illness'

[José Rizal, Noli me tangere [1878], apud Corpus del español, Mark Davies]

In such cases, the nature of habits as regular instantiations of an event in a sequence without inherent boundaries allows Spanish to take the duranteexpression as simply denoting a timespan which locates the habit without necessarily imposing an ending to it.

Russian can sometimes override the tendency to use Imperfective with time periods either in the case of a singular event that is conceived of as punctual rather than filling the time period as in example (16), or by means of morphology that specifies an external perspective, namely the use of the perdurative perfectivizing prefix pro- "through" as in example (17), or with a preposition like $z a$ "in" as in example (18).

(16) durante el primer día de batalla [during the.M.SG first.M.sG day of battle]- la infantería ligera persa se estrell-ó [crash-PST.PFV.3SG] contra la falange hoplita y se vio obligada a retirarse.

$v$ perv-yj že den' bitv-y [in first-ACC.M.SG day.ACc.sG battle-GEN.SG] legkaja persidskaja pexota na-tolknu-l-a-s' [on-clash.PFV-PST-F.SGREFL] na upornoe soprotivlenie tjaželovooružennyx grečeskix voinov (goplitov) i byla vynuždena otstupit’.

'during the first day of battle the Persian light infantry collided with the phalanx of Greek Hoplite soldiers and was forced to retreat.'

[Manuel P. Villatoro 2016.03.29, RNC] 
In example (16) the event is conceptualized as a point rather than a duration in Russian. The encounter with the Greek soldiers is portrayed as a punctual clash that happened at some unique time during the first day of the battle, not as an event that filled that day.

(17) Juan Rey... ejerci-ó [practice-PST.PFV.3SG] la abogacía en esta misma ciudad durante treinta año-s [during thirty year-PL]

Xuan Rej... tridcat' let [thirty-acc year.GEN.PL] pro-služi-l [throughserve.PFV-PST.M.SG] advokatom v samoj Sevil'e

'Juan Rey... practiced law in that same city (Seville) for thirty years'

[Benito Pérez Galdós 1876, RNC]

In example (17), both the Spanish and the Russian versions tell us that Juan Rey's career as a lawyer lasted 30 years. While the Perfective is the default for Spanish, in Russian it is occasioned by the prefixed Perfective verb pro-služit' [through-serve] "serve an entire period" that specifically marks entire careers or tours of duty and is always collocated with a time period. The effect in Russian is to place the observer outside and to make it possible to sequence this event with others (e.g., something that happened after someone completed their tour of duty).

(18) el francotirador aniquil-ó [annihilate-PST.PFV.3SG] a un total de entre 200 y 500 enemigos (atendiendo siempre a las diferentes fuentes) durante varia-s semana-s [during some-F-PL week-PL].

Za neskol'ko nedel' [in few.Acc week.GEN.PL] finskij snajper u-loži-l [down-lay.PFV-PST.M.SG] ot 200 do 500 (po raznym istočnikam) soldat protivnika.

'the sniper wiped out a total of between 200 and 500 enemy soldiers (according to different sources) in the course of a few weeks.'

[Manuel P. Villatoro 2016.09.16, RNC]

Here the Russian translation uses a temporal construction with the preposition $z a+$ Accusative, which has an absolute restriction to collocation with Perfective verbs. In effect, this construction expresses "get X done within time period Y" and is used to set deadlines for the completion of tasks. This construction is similar to the previous one in terms of setting the observer outside the time period.

The examples in this subsection show that for Spanish the default interpretation of a time period takes an external perspective, whereas the default 
interpretation in Russian takes an internal perspective. However, in neither case are speakers always "trapped" into a single interpretation. Both languages, at least in some contexts, allow both perspectives. However, extra context is needed to motivate non-default perspectives.

\subsection{Time until}

Spanish hasta "until" can be used to mark the endpoint of a time period ending with the fulfillment of a condition, roughly equivalent to Russian poka ne "until", and these constructions typically require that the verb describing the event that lasts up to the endpoint is Perfective in Spanish but Imperfective in Russian, as in this example from the Sombra database:

(19) Neri... hurg-ó [rummage-PST.PFV.3SG] en mis bolsillos hasta da-r con l-a-s llave-s [until give-INF with the-F-PL key-PL]. [S83:35]

Neri... šari-l [rummage.IPFV-PST.M.SG] po moim karmanam, poka ne naše$\boldsymbol{l}$ ključ-i [until not find.PFV-PST.M.SG key-ACC.PL]. [R67:2]

'Neri... rummaged in my pockets until he found the keys.' [E62]

An additional query for Spanish hasta was run in the parallel portion of the RNC. After cleaning to remove examples where hasta does not express "until" and/or is not collocated with a Past tense verb in Spanish, 60 examples remain. Of these, half (30 examples $=50 \%$ ) present the Spanish PFV $=$ Russian IPFV mismatch, as illustrated in this example:

(20) la Alcazaba conserv-ó [retain-PST.PFV.3SG] su importancia militar hasta el siglo XVIII [until the.M century XVIII].

krepost' Al'kasaba soxranja-l-a [retain.IPFV-PST-F.sG] svoe voennoe značenie vplot' do XVIII vek-a [up.to to XVIII century-GEN.SG].

'the Alcazaba fort retained its military importance up to the $18^{\text {th }}$ century.'

[Junta de Andalucía 2015, RNC]

There are various explanations for the 30 examples in our data that do not illustrate the aspectual mismatch. In 9 examples the Russian translation equivalent does not follow the Spanish closely enough to identify a parallel verb. The remaining examples show again that in both Russian and Spanish there are situations where one can depart from the default interpretation of a time period that is seen externally as bounded in Spanish (and therefore Perfective), but 
seen internally as durative in Russian (and therefore Imperfective). All of the Russian examples with Perfective verbs either involve morphology that specifies an external perspective (similar to example [17]) or a punctual event that does not fill the time period (similar to example [16]). The Spanish deviations from the default use of Perfective are mostly like those in Section 4.1, where the event is viewed from within as a habit (similar to example [15]). In addition, some examples show a use of hasta as a particular way of framing the event, as in this example, where we also reproduce the previous sentence in order to give a wider context:

(21) Un alemán no podía entregarse a la vida normal mientras su cuestionario, debidamente cumplimentado, no hubiese sido entregado y comprobado. Hasta entonces [until then] se halla-ba [be.found-PST.IPFV.3sG] fuera de la ley.

Nemec ne mog načat' normal'nuju žizn', poka zapolnennyj im oprosnyj list ne projdet proverku. A do t-ex por [to that-GEN.PL time.GEN.PL] on naxodi-l-sja [find.IPFV-PST.M.SG-REFL] kak by vne zakona.

'A German could not have a normal life as long as the properly completed questionnaire had not been delivered and checked. Until that time he existed outside the law.'

[Manuel P. Villatoro 2015.01.19, RNC]

Beyond the non-specific flavor of the situation, which applies to any German and not to a specific one, what is crucial in such cases is that the hastaconstruction is not used to mark the endpoint of the situation described by the verb: it does not follow from (21) that a German would change his legal status from that moment onwards. Instead, hasta introduces a set of situations that frame the claim made by the sentence, almost in the form of a conditional statement. Entonces "then" in the wider context refers to a condition, namely that the questionnaire be filled out and delivered to the authorities: if this condition is not met, the person is an outlaw; if it is met, the situation could change. Hasta, then, does not delimit the timespan because there is no guarantee that the event used to delimit it would happen.

The Spanish hasta "until" construction opens up a whole range of ways in which a bounded time span can be expressed even without overt reference to a time period. For example, one event can be bounded by another, as we see in this example, where the subject's working is bounded by his death, and again we encounter the Spanish PFV = Russian IPFV mismatch: 
(22) Lluís Domènech i Montaner... trabaj-ó [work-PST.PFV.3sG] hasta su muerte [until 3sG.Poss death] en la construcción del recinto de Sant Pau. L'juis Domenek i Montaner... rabota-l [work.IPFV-PST.M.SG] nad proektom bol'nicy Sant Pau praktičeski do sam-oj smert-i [to very-GEN.F.SG deathGEN.SG].

'Lluís Domènech i Montaner... worked until his death on the Sant Pau project.'

[Sant Pau 2013, RNC]

We explore further how Spanish infers bounded time spans in Section 4.3.

\subsection{Inferred temporal boundaries}

Spanish can use the Perfective Past tense even in situations where the final boundary is not overtly stated, but only inferred through the wider context. Compare the previous example (22) to the one that follows. Both examples describe a situation that obtained until an individual died, and both illustrate the Spanish PFV=Russian IPFV mismatch. In the previous example, death is explicitly named as the terminal boundary for working. In example (23), there is no mention of the death, but because suffering from a chronic disease is something that ceases when a person dies, and because all people die, Spanish is able to infer that the woman's suffering the disease must have ended at some point, and therefore a Perfective form is used to mark this as a closed time span. Even though the Russian translation (unlike the Spanish original) makes an explicit reference to the lifetime with the prepositional phrase pri žizni "while alive”, Russian requires the use of an Imperfective verb.

(23) En palabras de la arqueóloga... una de las personas enterradas (la mujer) tuv-o [have-PST.PFV.3SG] cifosis

Po slovam arxeologa... odno iz zaxoronennyx tel prinadležalo ženščine, kotoraja při žizni strada-l-a [suffer.IPFV-PST-F.SG] kifozom

'In the words of the archeologist... one of the people who were buried (the woman) had kyphosis'

[Media [www.abc.es] 2016.12.19, RNC]

Of course, not just human beings, but all things come to an end, making it possible to infer endpoints for other situations as well in Spanish, as in example (24), taken from a historical description of the Andalusian city Almería. Here what is inferred as 
coming to an end is the city's preponderant role as a harbor in the Mediterranean. Even though only the beginning point is named here, given that the text is a historical description it is assumed that there must be an ending as well. Again, we find a Perfective form in Spanish, but an Imperfective form in Russian.

(24) Desde los tiempos del emirato, Almería jug-ó [play-PST.PFV.3sG] un papel preponderante como puerto marítimo y escala comercial.

So vremen èmirata Al'merija igra-l-a [play.IPFV-PST-F.sG] dominirujuščuju rol' kak morskoj port i torgovyj uzel.

'Since the time of the emirate, Almería played a dominating role as a maritime port and trading post.'

[Junta de Andalucía. Almería 2015, RNC]

The Spanish inference of boundaries extends to situations modified with the adverb siempre "always", as we see in the next example. Even if we say that something "always" happened, the real extent of the situation is necessarily finite, not infinite, and contextually delimited either by the lifetime of individuals or things, or by other relevant timespans salient in the text. Under these conditions, Spanish uses the Perfective. This is diametrically opposed to the norm in Russian, where the use of vsegda "always" usually requires the Imperfective.

(25) yo siempre [always] le tuv-e [have-PST.PFV.1SG] por un sinvergüenza. [S95:16]

ja ego vsegda [always] derža-l [held.IPFV-PST.M.sG] za bessovestnuju skotinu. [R79:38]

'To me he was always a scoundrel.' [E72]

In (25), "always" is contextually restricted by the timespan which starts when the speaker gets to know the person discussed, and whose ending can be defined in different ways: either the person died, and with him the property evaluated, or the present moment sets the boundary ("until this very moment"). In either case, Spanish presents the evaluation as unchanged, complete and definite, suggesting it has never changed for the speaker.

\subsection{Historical present}

Because Russian marks aspect on all verb forms regardless of tense and other categories, a portion of examples of the Spanish PFV = Russian IPFV mismatch 
involve Russian verb forms that are Imperfective, but not Past tense. One particularly relevant comparison arises in cases where Russian uses a historical Present as the equivalent of a Spanish Past Perfective form. In Russian the historical Present is necessarily Imperfective, and Janda (2004: 503) and Dickey (2000: Ch. 4) suggest that this device situates the observer inside the event as if it is currently ongoing.

(26) Celestino di-o [give-PST.PFV.3sg] una vuelta, tenía la boca seca. La fuerza empez-ó [begin-PST.PFV.3SG] a desdibujarse, a hacerse un poco confusa... Celestino Ortiz se levant-ó [rise-PST.PFv.3sG]de su jergón, encendi-ó [turn.on-PST.PFV.3SG] la luz del bar, tom-ó [take-PST.PFV.3SG] un traguito de sifón y se meti-ó [go.into-PST.PFV.3SG] en el retrete.

Selestino povoračiva-et-sja [turn.IPFV-NPST.3SG-REFL], vo rtu u nego peresoxlo. Očertanija otrjada načinaj-ut [begin.IPFV-NPST.3PL] rasplyvat'sja, zavolakivat'sja tumanom... Selestino Ortis podnima-et-sja [rise.IPFVNPST.3SG-REFL] so svoego matraca, vključa-et [turn.on.IPFV-NPST.3SG] svet, otpiva-et [drink.IPFV-NPST.3sG] glotok iz sifona $i$ idet [walk.IPFVNPST.3SG] $v$ ubornuju.

'Celestino turned around, his mouth was dry. The troops began to dissolve, to become rather hazy... Celestino Ortiz got up off of his mattress, turned on the light, took a swallow from the tap, and went to the bathroom.'

[Camilo José Cela 1951, RNC]

This example shows a sequence of six events, all of which are expressed from an external viewpoint with Spanish Past Perfective forms, but expressed by Russian Imperfective Present (Non-past) verb forms.

\subsection{Other factors}

In addition to the difference in viewpoint demonstrated in Sections 4.1-4.4, other lesser factors come into play in the difference between Spanish and Russian aspect. These include various language-specific facts about lexical items, idioms, and grammatical categories in the two languages.

In Russian, some Imperfective verbs lack a Perfective partner verb of the same lexical meaning, and this may contribute to the pervasiveness of the Spanish PFV = Russian IPFV mismatch. The most important is the verb byt' "be", with an illustration of a mismatch in example (11) in Section 4.1 above. 
Although Russian byt" "be" is usually listed as an imperfective tantum verb, the aspectual status of this verb is controversial: Padučeva (2015) suggests instead that this verb is actually biaspectual (expressing both Perfective and Imperfective aspect), and a recent quantitative analysis of Russian corpus material (Eckhoff et al. 2017) confirms this suggestion. Another relevant verb is moč' "be able", where the purported Perfective partner verb smoč' means something more like "succeed, manage to". Taken together, Imperfective forms of these two verbs account for only 15 of the aspectual mismatches reported in Table 2, including this example which is idiomatic in both languages, requiring Perfective for Spanish, but Imperfective for Russian ${ }^{8}$ :

(27) Cuál fu-e [be-PST.PFV.3Sg] su sorpresa cuando, cientos de kilómetros más tarde, descubrió que... [S42:14]

Kakovo že by-l-o [be.IPFV-PST-N.SG] ego udivlenie, kogda, proexav sotni kilometrov, on obnaružil, čto... [R26:28]

'Much to his surprise, hundreds of kilometers later, he discovered...' [E24]

Russian has a strong preference for Imperfective verbs in collocation with manner adverbs, commonly explained as an indication that the adverb turns the attention to the inner structure of an event and how it unfolds (cf. Janda 2004: 499). Here is an illustration of the Spanish PFV = Russian IPFV mismatch that can be at least partially attributed to the presence of an adverb:

(28) Rusia luch-ó [fight-PST.PFV.3SG] duramente [harshly] contra turcos, franceses e ingleses para mantener Crimea.

Rossija ožestočenno [bitterly] boro-l-a-s' [fight.IPFV-PST-F.SG-REFL] $s$ turkami, francuzami i angličanami za obladanie Krymom.

'Russia fought ferociously against the Turks, the French, and the English to maintain control of the Crimea.'

[Francisco López-Seivane 2016.10.24, RNC]

\footnotetext{
8 In the web-based portion of Corpus del Español (2 billion words), there is not a single occurrence of this expression with Imperfective Past; of the cases that appear in Past form, 65\% are Perfective, and all remaining cases are conditional (seria "would be"). There are 383 attestations of this expression in the Russian National Corpus, all using the Imperfective: 379 are Past tense, the remaining four are Future.
} 
There are several peculiarities of Russian aspect that encourage the use of Imperfective verbs where Spanish requires a Perfective form. These phenomena are marginal in our data, accounting for between one and four examples each. One is categorical negation, where Russian uses multiple negation and the Russian Imperfective has the effect of spreading the negation to blanket all possibilities (cf. Janda 2004: 496), as in this example:

(29) después de aquel día, Nuria nunca más [never more] volvi-ó a sabe-r [resume-PST.PFV.3SG to know-INF] de Carax [S96:1]

s tex por Nurija ni-kogda ni-č-ego ne [no-when no-what-GEN not] slyšal-a [hear.IPFV-PST-F.SG] o Karakse [R80:32]

'after that day Nuria didn't hear from Carax again' [E73]

Another phenomenon is the Russian "general-factual" use of the Imperfective (cf. Janda 2004: 506; Comrie 1976: 113; Čertkova 1996: 95), used as a backgrounding device to refer to an event completed in the past, but not part of a sequenced plotline. The general-factual merely establishes that something took place without any focus on the result. The following example illustrates how the Russian general-factual contributes to the Spanish PFV = Russian IPFV mismatch.

(30) Me acuerdo hasta de la cara de una gitana que nos ley-ó [read-PST. PFV.3sG] la mano en la playa del Bogatel [S97:58]

Ja daže pomnju lico cyganki, kotoraja gada-l-a [guess.IPFV-PST-F.sG] nam po ruke na pljaže Bogatel' [R82:21]

'I even remember the face of a Gypsy woman who read our fortune on El Bogatell beach' [E74]

In this example, an old man vividly remembers his first love affair, which involved going to the beach to get their fortune told. This was a single completed event, but since it is backgrounded in the description, its presence is merely established by the Imperfective in Russian.

Spanish has no device directly corresponding to the general-factual use of the Imperfective and uses the Perfective as expected. However, there is a small set of cases in which Spanish uses Imperfective stylistically to remove from focus the event expressed by the verb so that it appears less individuated within the narration and more integrated with the other events reported (Reyes 1990; Bres 2005). This is illustrated in (31) with an example from the Sombra corpus. 
(31) Al irrumpi-r [when break.in-INF] una noche en una mansión... de un magnate..., su hija, una señorita de la buena sociedad parisina... se enamora-ba [fell.in.love-PST.IPFV.3sG] del ladrón. [S41:9]

Odnaždy nočju, ... on pronik [break.in.PFV.PST.M.SG] $v$ respektabel'nyj dom..., prinadležavšij odnomu iz magnatov... Doč’ magnata, izyskannaja, obrazovannaja děvuška, vxožaja $v$ vysšij svet, vospyla-l-a [be.smitten. PFV-PST-F.SG] $k$ voru ljubov-n-oj strast'-ju [love-ADJ-INS.F.SG passionINS.SG]. [R25:22]

'One fateful night he [the thief] breaks into a sumptuous mansion... belonging to a tycoon... [whose] daughter, a young lady of Parisian high society... [was] doomed to fall in love with the intruder' [E23]

The stylistic effect of the Imperfective in Spanish is to suggest that the two events the thief's breaking in, and the lady's falling in love with him- were simultaneous or virtually indistinguishable from each other. In Russian, on the contrary, these two events are reported as a sequence of events using Perfective verbs.

Finally, if an action has been both completed and then reversed, then Russian prefers the Imperfective in a use termed the "annulled event" (Janda 2004: 510-511). This is most common with verbs that involve a change in position, such as opening (and then closing) a door or window, or traveling from point $A$ to point $B$ (and then back again to point A), or taking up a position and then leaving it, as in this example.

(32) Sé que una vez, en el 32 o el 33, Nuria viaj-ó [travel-PST.PFV.3SG] a París por asuntos de Cabestany, y que se aloj-ó [lodge-PST.PFV.3sG] en casa de Julián Carax un par de semanas. [S94:46]

Znaju, čto odnaždy, v 1932-m ili $v$ 1933-m, ona ezdi-l-a [ride.IPFV-PST-F.SG] $\checkmark$ Pariž po delam Kabestanja i ostanavliva-l-a-s' [fight.IPFV-PST-F.SGREFL] na paru nedel' u Xuliana Karaksa. [R78:64]

'I know that once, in 1932 or 1933, Nuria went to Paris on business for Cabestany, and she stayed in Julián Carax's apartment for a couple of weeks.' [E72]

Nuria has taken a round trip from Barcelona to Paris and back, and this is made clear by the use of the "annulled event" Imperfective in Russian, whereas Spanish uses the Perfective as expected, because both verbs are bounded: the first one by the arrival in Paris, and the second one by the expression un par de semanas "a couple of weeks". 


\section{Conclusions}

This analysis shows how a linguistic category can vary across languages, detailing differences in construal and conceptual categorization and thus elaborating on these theoretical concepts.

The distinction of Perfective vs. Imperfective is not quite the same in Spanish as it is in Russian, and in this study, we cite specific ways in which the aspectual systems of these two languages diverge. The most notable difference is that there are contexts that select Perfective in Spanish but Imperfective in Russian. In parallel Spanish-Russian texts, this mismatch in aspect is typically found in situations that involve a period of time. Any extent of time, no matter how long or short, can yield Perfective in Spanish but Imperfective in Russian. The same is true of contexts in which a time period is overtly stated, as well as in situations that specify or even merely infer the presence of a final boundary.

Our specific findings involve five groups of contexts in which Spanish prefers a Perfective verb form while Russian prefers an Imperfective. The first group (see Section 4.1) includes overt expressions of time periods filled with an event. The time period can be specified in a variety of grammatical constructions that include prepositional phrases, numerals, and nouns denoting time. The second group (see Section 4.2) includes constructions that focus on a duration that is bounded by an endpoint marked by expressions like hasta in Spanish and poka ne in Russian, both of which can be translated as "until". In the third group of contexts (see Section 4.3), an endpoint is not overtly stated but can be inferred with respect to the existence of people and things that cannot survive indefinitely. The fourth group (see Section 4.4) is motivated by the Russian historical Present construction, which requires an Imperfective, and is often used as the translation equivalent of a sequence of completed events rendered by Perfective verb forms in Spanish. Other factors collected in the fifth group (see Section 4.5) pertain to peculiarities of Russian, which prefers the Imperfective in constructions with manner adverbs, categorical negation, "general-factual" statement of events, and annulled events.

In schematic terms, in a construal such as the one in Figure 2, where the eventuality is bounded by explicit or contextual limits, Russian still contemplates the eventuality from within the boundaries, with duration being a central factor motivating Imperfective; Spanish conceptualizes the situation from without, and is therefore forced to use Perfective.

In Figure 2 we juxtapose the two aspectual perspectives on a situation that unfolds over time as presented in Figure 1. The dashes represent the temporal 


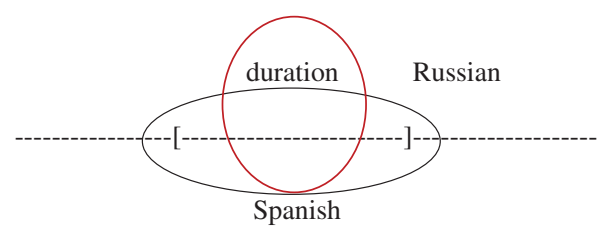

Figure 2: Aspect from within and aspect from without.

extension of a situation with a given duration, and the square brackets represent the initial and final boundaries of the situation. The two ellipses represent the different perspectives of Spanish and Russian with respect to the situation when a Spanish Perfective is matched by a Russian Imperfective. The wider black ellipse is the Spanish perspective, including the boundaries, whereas the narrower red ellipse is the Russian perspective, excluding the boundaries.

Our analysis is that the Spanish PFV= Russian IPFV mismatch indicates a difference in the way that time periods are conceptualized in the two languages. In Spanish, time periods are typically seen as if from without, comparable to Langacker's (2008: 65) "maximal scope”, whereas in Russian, time periods are typically seen from within, comparable to "immediate scope". ${ }^{9}$ While this interpretation is limited to the samples cited here, it suggests a link between different conceptualizations and differences in the grammars of language.

To return to example (1), in Spanish Bea reports her experience of thinking that she will remain alone as a situation that has been brought to a close and that she can see from without now that Daniel has arrived. But in Russian, Bea must report her experience from within, because her thinking lasted some time. The real world might be identical, but the way in which each language conceptualizes the situation is markedly different, which implies that Spanish Perfective cannot be equated to Russian Perfective.

Acknowledgements: The authors would like to thank their employer, UiT The Arctic University of Norway, for supporting their research. We are also grateful to the three anonymous reviewers for their constructive comments, which have contributed to shape this article.

9 Our results are compatible with Westerholm (2010), who argues after a detailed quantitative analysis of Spanish and Russian past forms that Spanish imperfective is insensitive to durativity, unlike Russian which is mainly defined by durativity and iterativity. Westerholm (2010) aligns himself with Bello (1847) in the idea that the Spanish imperfecto is sensitive to simultaneity with another past eventuality. See also Castañeda (2006) on the role that simultaneity has in the Spanish imperfecto. 


\section{Abbreviations}

In all examples we use the standard abbreviations of the Leipzig Glossing Rules (https://www.eva.mpg.de/lingua/pdf/Glossing-Rules.pdf). The relevant abbreviations in this article are as follows: 1 "first person", 2 "second person", 3 "third person", ACC "accusative”, ADJ "adjective”, COND "conditional”, F "feminine”, GEN "genitive”, INF “infinitive”, INS "instrumental”, IPFV “imperfective”, LOC "locative”, M “masculine”, N "neuter”, NOM "nominative”, NPST "nonpast”, PFV “perfective”, PL “plural”, POSS “possessive”, PST “past”, REFL “reflexive”, SG "singular”.

\section{References}

Alarcos Llorach, Emilio. 1949. Sobre la estructura del verbo español moderno. Boletín de la Biblioteca Menéndez Pelayo 15. 50-80.

Alcina, Juan \& José Manuel Blecua. 1975. Gramática española. Barcelona: Ariel.

Arche, María J. 2014. About the primitives of aspect across languages. Natural Language and Linguistic Theory 32. 711-733.

Bach, Emmon. 1986. The algebra of events. Linguistics and Philosophy 9. 5-16.

Bello, Andrés. 1847. Gramática de la lengua castellana destinada al uso de los americanos [Ed. 1981]. Santa Cruz de Tenerife: Instituto Universitario de Lingüística Andrés Bello.

Bertinetto, Pier Marco. 2004. Estativos, progresivos, habituales. In Luis García Fernández \& Bruno Camus Bergareche (eds.), El pretérito imperfecto, 273-346. Madrid: Gredos.

Bres, Jacques. 2005. L'imparfait dit narratif. Paris: CNRS Editions.

Brucart, José María. 2003. El valor del imperfecto de indicativo en español. Reports de recerca GGT-03-1. Barcelona: Universitat Autònoma de Barcelona.

Bull, William E. 1960. Time, tense and the verb. Berkeley: University of California Press.

Carlson, Gregory. 2011. Habitual and generic aspect. In Robert Binnick (ed.), The Oxford handbook of tense and aspect, 828-852. Oxford: Oxford University Press.

Carrasco, Ángeles \& Luis García Fernández. 1994. Sequence of tense in Spanish. Working Papers in Linguistics of the University of Venice 4. 45-70.

Castañeda, Alejandro. 2006. Aspecto, perspectiva y tiempo de procesamiento en la oposición imperfecto/indefinido en español. Ventajas explicativas y aplicaciones pedagógicas. Revista Española de Lingüística Aplicada 5. 107-140.

Castañeda, Alejandro \& Zeina Alhmoud. 2014. Una aproximación al sistema verbal aplicable a la enseñanza de ELE. In Alejandro Castañeda (ed.), Enseñanza de gramática avanzada de ELE: Criterios y recursos, 267-294. Madrid: SGEL.

Castañeda, Alejandro \& Rosario Alonso. 2009. La percepción de la gramática. Aportaciones de la lingüística cognitiva y la pragmática a la enseñanza del español/LE. MarcoELE 8. 1-33.

Čertkova, Marina J. 1996. Grammatičeskaja kategorija vida v sovremennom russkom jazyke [The grammatical category of aspect in modern Russian]. Moscow: Moscow State University.

Comrie, Bernard. 1976. Aspect. Cambridge: Cambridge University Press. 
Croft, William. 2001. Radical construction grammar. Oxford: Oxford University Press.

Croft, William. 2012. Verbs: Aspect and causal structure. Oxford: Oxford University Press.

Dahl, Östen. 1981. Tense and aspect systems. Oxford: Blackwell.

de Jonge, Bob. 2000. Eventuality classification. Meaning and use of Spanish simple past tenses. In Yishai Tobin \& Ellen Contini-Morava (eds.), Lexical and grammatical classification: Same or different? 227-253. Amsterdam: John Benjamins.

De Mello, George. 1989. Some observations on Spanish verbal aspect. Hispanic Linguistics 3. 123-129.

De Swart, Henriette. 2011. Verbal aspect. In Robert Binnick (ed.), The Oxford handbook of tense and aspect, 752-781. Oxford: Oxford University Press.

Dickey, Stephen M. 2000. Parameters of Slavic aspect. A cognitive approach. Stanford: CSLI Publications.

Dickey, Stephen M. \& Laura A. Janda. 2015. Slavic aspectual prefixes and numeral classifiers: Two kinds of lexico-grammatical unitizers. Lingua 168. 57-84.

Díez, Tatiana D. 2002. Gramática del tiempo y del aspecto en ruso y en español: Similitudes y divergencias. Eslavistica Complutense 2. 33-44.

Doiz Bienzobas, Aintzane. 1995. The preterit and the imperfect in Spanish: Past situation vs. past viewpoint. San Diego: University of California Ph.D. dissertation.

Eckhoff, Hanne M., Laura A. Janda \& Olga Lyashevskaya. 2017. Predicting Russian aspect by frequency across genres. Slavic and East European Journal 64(1). 844-875.

Fábregas, Antonio. 2015. Imperfecto and indefinido in Spanish: What, where and how. Borealis 4. $1-70$.

Forsyth, J. 1970. A grammar of aspect: Usage and meaning in the Russian verb. Cambridge: Cambridge University Press.

García, Erica C. \& F. C. M. van Putte. 1988. The value of contrast: Contrasting the value of strategies. International Review of Applied Linguistics in Language Teaching 26(4). 263280.

García Fernández, Luis. 2000. La gramática de los complementos temporales. Madrid: Visor.

García Fernández, Luis. 2004. El pretérito imperfecto: Repaso histórico y bibliográfico. In Luis García Fernández \& Bruno Camus Bergareche (eds.), El pretérito imperfect, 13-96. Madrid: Gredos.

Gili Gaya, Samuel. 1943. Curso superior de sintaxis española. Barcelona: Bibliograf.

Gorbova, Elena V. 2002. Oppozicija imperfekt/aorist v ispanskom jazyke [The imperfect/aorist opposition in Spanish]. In Voronežskij gosudarstvennyj universitet inženernyx texnologij (ed.), Materialy XXXI Vserossijskoj naučno-metodičeskoj konferencii prepodavatelej $i$ aspirantov. Vyp.22. Sekcija obščego jazykoznanija. Č.1, 13-18. St.Petersburg: SPGU.

Gorbova, Elena V. 2010. Grammatičeskaja kategorija aspekta i kontekst (na materiale ispanskogo i russkogo jazykov) [The grammatical cateogory of aspect in context (based on material from Spanish and Russian)]. St. Petersburg, Russia: St. Petersburg State University Doctoral dissertation.

Gorbova, Elena V. 2013. Ispanskij perfekt: Ešče perfekt ili uže perfektiv/preterit? [The Spanish perfect: Still perfect or already perfective/preterite?]. Voprosy jazykoznanija 4. 97-125.

Gorbova, Elena V. 2014. Perfektnaja semantika v russkom jazyke i semantika perfekta v ispanskom [Perfective semantics in Russian and the semantics of the perfect in Spanish]. Scando-Slavica 60(2). 275-321. http://dx.doi.org/10.1080/00806765.2014.984466.

Gras, Pedro \& Marisa Santiago. 2012. Cómo hacer la gramática significativa: Aspecto léxico y aspecto gramatical. Mosaico 30. 19-25. 
Gutiérrez Araus, María L. 1995. Formas temporales del pasado en indicativo. Madrid: Arco Libros.

Gvozdanović, Jadranka. 2011. Perfective and imperfective aspect. In Robert Binnick (ed.), The Oxford handbook of tense and aspect, 781-803. Oxford: Oxford University Press.

Hernández Alonso, César. 1984. Gramática funcional del español. Madrid: Gredos.

Jakobson, Roman 0 (ed.). 1971a. Zur Struktur der russischen Verbums. In Selected Writings II: Word and Language, 3-15. The Hague: Mouton.

Jakobson, Roman 0 (ed.). 1971b. Shifters, verbal categories, and the Russian verb. In Selected writings II, 130-147. The Hague: Mouton.

Janda, Laura A. 2004. A metaphor in search of a source domain: The categories of Slavic aspect. Cognitive Linguistics 15(4). 471-527.

Janda, Laura A. 2007a. Inflectional morphology. In Dirk Geeraerts \& Hubert Cuyckens (eds.), Handbook of cognitive linguistics, 632-649. Oxford: Oxford University Press.

Janda, Laura A. 2007b. Aspectual clusters of Russian verbs. Studies in Language 31(3). 607-648.

Janda, Laura A. 2012. Russkie pristavki kak sistema glagol'nyx klassifikatorov [Russian prefixes as a verb classifier system]. Voprosy jazykoznanija 6. 3-47.

Janda, Laura A., Anna Endresen, Julia Kuznetsova, Olga Lyashevskaya, Anastasia Makarova, Tore Nesset \& Svetlana Sokolova. 2013. Why Russian aspectual prefixes aren't empty: Prefixes as verb classifiers. Bloomington, IN: Slavica Publishers.

Janda, Laura A. \& Olga Lyashevskaya. 2011. Grammatical profiles and the interaction of the lexicon with aspect, tense and mood in Russian. Cognitive Linguistics 22(4). 719-763.

Kargovskaya, Elena A. 2012. Algunos medios de expresar la aspectualidad de la accion en ruso y español. Cuadernos de Rusîstica Española 8. 57-67.

Klein, Wolfgang. 1994. Time in language. London: Routledge.

Krifka, Manfred, Francis J. Pelletier, Gregory N. Carlson, Alice ter Meulen, Gennaro Chierchia, Godehard Link, et al. 1995. Genericity: An introduction. In G. Carlson (ed.), The generic book, 1-124. Chicago: University of Chicago Press.

Langacker, Ronald W. 1987. Foundations of cognitive grammar. vol. I. Stanford: Stanford U Press.

Langacker, Ronald W. 2008. Cognitive grammar. Oxford: Oxford University Press.

Maslov, Jurij S. 1965. Sistema osnovnyx ponjatij i terminov slavjanskoj aspektologii [The system of basic concepts and terms for Slavic aspectology]. Voprosy obščego jazykoznanija 1. 53-80.

Padučeva, Elena V. 2015. O biaspektual'nosti russkogo glagola BYT' [The biaspectuality of the Russian verb BYT']. In M. Kitadzë (ed.), Aspektual'naja zona: Tipologija sistem i scenarii diaxroničeskogo razvitija. Sbornik statej V Meždunarodnoj konferencii Komissii po aspektologii Meždunarodnogo komiteta slavistov, 176-184. Kyoto: University of Kyoto.

Palacio Alegre, Blanca. 2009. Pretérito imperfecto de indicativo: Valor operativo y contraste con el pretérito indefinido. redELE 15. 1-34.

Palacio Alegre, Blanca. 2016. Gramática cognitiva-operativa: Limitaciones de una instrucción única. El caso del imperfecto/indefinido en el aula de ELE. Revista electrónica de didáctica del español como lengua extranjera 22. 1-26.

Plungian, Vladimir. 1998. Perfektiv, kompletiv, punktiv: Terminologija i tipologija [Perfective, completive, punctive: Terminology and typology]. In M. J. Čertkova (ed.), Tipologija vida, 370-381. Moscow: Škola “Jazyki russkoj kul'tury”. 
Plungian, Vladimir. 2011. Vvedenie v grammatičeskuju semantiku: Grammatičeskie značenija $i$ grammatičeskie sistemy jazykov mira [Introduction to grammatical semantics: the grammatical meaning and grammatical systems of languages of the world]. Moscow: RGGU.

RAE \& ASALE. 2009. Nueva gramática de la lengua española. Madrid: Espasa.

Reyes, Graciela. 1990. Valores estilísticos del imperfecto. Revista de filología española 70. 45-70. Rojo, Guillermo. 1974. La temporalidad verbal en español. Verba 1. 68-149.

Rojo, Guillermo. 1976. La correlación temporal. Verba 3. 65-89.

Rojo, Guillermo \& Alexandre Veiga. 1999. El tiempo verbal: Los tiempos simples. In Ignacio Bosque \& Violeta Demonte (eds.), Gramática descriptiva de la lengua española, 2867-2935. Madrid: Espasa.

Ruiz Campillo, José P. 2000. ‘Tomaban’ o ‘tomaron'. Una visión operativa y cognitiva del problema. Centro Virtual Cervantes, post from 12th of December 2000. Available at https://cvc.cervantes.es/foros/leer_asunto1.asp?vCodigo=5652\#19299

Ruiz Campillo, José P. 2005. Instrucción indefinida, aprendizaje imperfecto. Para una gestión operativa del contraste imperfecto/indefinido en clase. Mosaico 15. 9-17.

Slobin, Dan I. 1996. From "thought and language" to "thinking for speaking”. In John J. Gumperz \& Stephen C. Levinson (eds.), Rethinking linguistic relativity, 70-96. Cambridge: Cambridge University Press.

Timberlake, Alan. 2004. A reference grammar of Russian. Cambridge: Cambridge University Press. Veiga, Alexandre. 2015. La gramática académica y los problemas del aspecto en la descripción del verbo español. Borealis 4. 119-150.

Vinogradov, Viktor V. 1972. Russkij jazyk [The Russian language], 2nd edn. Moscow: Vysšaja škola.

Westerholm, David. 2010. Funciones del pasado en los sistemas verbales del español y del ruso. Acta-Romanica Gothoburgensis. vol. 66. Göteborg: Göteborgs Universitet.

Zagona, Karen.. 2012. Tense and aspect. In J. I. Hualde et al. (ed.), The handbook of hispanic linguistics, 355-373. London: Wiley-Blackwell.

Zaliznjak, Anna A. \& Aleksei D. Šmelev. 2000. Vvedenie v russkuju aspektologiju [Introduction to Russian aspectology]. Moscow: Jazyki russkoj kul'tury.

\section{References for the sources in the examples}

Ruiz Zafón, Carlos. 2001. La Sombra del Viento. Barcelona: Planeta. (=S)

Ruiz Zafón, Carlos. 2004. The Shadow of the Wind. (English translation of La Sombra del Viento by L. Graves). New York: Penguin Press. (=E)

Ruiz Zafón, Carlos. 2016. Ten' vetra. (Russian translation of La Sombra del Viento by

M. Smirnova \& V. Temnov). Moscow: ACT. (=R)

Russian National Corpus (=RNC). http://ruscorpora.ru/old/en/

Complete information about the examples from the databases with their sources can be found as publicly available material under the following reference:

Janda, Laura \& Antonio Fábregas. 2019. Replication Data for: "Seeing from without, seeing from within: aspectual differences between Spanish and Russian". The Tromsø Repository of Language and Linguistics. https://doi.org/10.18710/WR4Y0Q 